\title{
Italian Sacred Music Listed in the Catalogue of Dresden's Catholic Court Church, 1765
}

\author{
Janice B. Stockigt / j.stockigt@unimelb.edu.au
}

Faculty of Fine Arts and Music, The University of Melbourne, Victoria, AU

\begin{abstract}
Analysis of more than 800 items of sacred music listed in the thematic catalogue ("Catalogo della Musica di Chiesa composta Da diversi Autori - secondo l'Alfabetto 1765") of Dresden's Catholic court church (the Hofkirche) demonstrates the dependence of this church upon compositions by Italian composers. Apart from existing repertoire, important transmissions of Italian music into Saxony came through the personal collections of the church composers Jan Dismas Zelenka (1679-1745) and Giovanni Alberto Ristori (1699-1754), composers whose musical estates came to be acquired by the Dresden court. Valuable additions came from members of the electoral and royal family, while an important corpus of Italian sacred works came into the collection of the Hofkirche to be entered into the Catalogo by Schürer. This late repertoire came from the Venetian copying house of Iseppo Baldan and it contained more than seventy sacred items attributed to Baldassare Galuppi (1706-1785).

An overview of the main contributors to the Dresden collection as it was catalogued in 1765 is presented. The principal Italian composers of Dresden's sacred Catholic repertoire of music are named and the collectors are identified. A possible purpose is proposed for the acquisition of the many items from Iseppo Baldan. Finally, the transmission of the Italian repertoire from Dresden demonstrates the ongoing movement of Italian sacred music to German centres such as Leipzig and Berlin.
\end{abstract}

\section{Keywords}

Dresden, Italian sacred music, Jan Dismas Zelenka, Giovanni Alberti Ristori, Baldasarre Galuppi, Iseppo Baldan, Johann George Schürer, music catalogues 
In March 1765, the Bohemian-born church composer of the Dresden court Johann Georg Schürer (1720-1786) finalized a thematic catalogue of the sacred music collection that then was kept in the recently built Catholic court church. This Hofkirche (dedicated in 1751) was established by the hereditary elector of Saxony Frederick Augustus II who, as elective king of Poland, was titled August III. The Hofkirche replaced the original smaller royal chapel established in 1708 by his father, Saxon Elector Friedrich August I who, as King of Poland, was titled August II ("the Strong"). ${ }^{1}$ The thematic inventory of 1765 titled "Catalogo della Musica di Chiesa composta Da diversi Autori - secondo l'Alfabetto 1765 " is in three volumes. Today it is kept in the Staatsbibliothek zu Berlin, Preußischer Kulturbesitz, Musikabteilung (D-B). ${ }^{2}$ Sacred works entered into the Catalogo either were written for or acquired to serve the musical requirements of Dresden's two post-Reformation Catholic court churches. Given the taste of August III for the arts of Italy it is not surprising that many works by Italian composers are found among the more than 800 listed items. Concordances found today in Czechian archives and eighteenth-century inventories reveal the great importance of Bohemian institutions in the transmission of Italian sacred works to Saxony.

Of approximately 134 composers Schürer listed in the Catalogo at least ninety have Italian names. Nevertheless, among the genuine Italian composers mis-attributions are found. This overview itemizes the Italian composers whose sacred works entered the repertoire of Dresden's Hofkirche, contributions made from collections of musicians of the Dresden court are given, and works wrongly attributed to Italians are identified.

\section{Development of the Collection}

The most important contributors to Italian sacred music in Dresden's collection as catalogued in 1765 were the court church composers Jan Dismas Zelenka (1679-1745) and Giovanni Alberto Ristori (1699-1753). To a lesser extent Kapellmeister Johann David Heinichen (1663-1729) added sacred items from Italy to the repertoire, while members of the ruling Saxon family also contributed. The Jesuits who served Dresden's royal Catholic church probably were responsible for the early acquisition of published music by Italians to be used by the Bohemian ensemble of young musicians (Kapellknaben) of the original church. Queen Maria Josepha (1699-1757), wife of August III, came to take responsibility for the music of both royal chapels, a duty inherited by her daughter-inlaw, Maria Antonia. ${ }^{3}$ Maria Josepha also ensured the purchase of sacred music once held

1 The preparation of this article was greatly assisted by Jóhannes Ágústsson, Susanne Haring, and Shelley Hogan. Their help is gratefully achnowledged.

The conversion in 1696 to Catholicism of Friedrich August I enabled him to become an eligible candidate for the throne of Poland. In 1712 his son and successor, Friedrich August II (1697-1763), also converted to Catholicism. In 1733, he was elected King of Poland.

2 D-B, Mus. ms. theor. Kat. 186.

3 This responsibility undertaken by these two successive Saxon electresses is known from an invoice submitted to the court dated 27. 3. 1765: "Ich habe von denen neuerl. [ich] verfertigten 2. Catalogis des Churfl. 
by her court composers. ${ }^{4}$ It was she who acquired the musical estates and collections of Zelenka and Ristori, music that by 1765 formed the backbone of the Hofkirche collection. In addition, the large collection of sacred music from the Venetian copying house of Iseppo Baldan added new stylistic dimensions to the repertoire: approximately seventythree works delivered by Baldan were attributed to Baldassare Galuppi "Il Buranello" (1706-1785), a Venetian whose music represented the new galant style of the mid-1700s.

Late in 1764, soon after the end of the Third Silesian War (1756-1763), Schürer began to oversee the systematic cataloguing and storage of Dresden's collection of sacred music. An invoice he presented to the court gave the cost of repairs to cupboards and their removal from the late Queen's apartments into the Hofkirche. Schürer also itemized materials needed for the preparation of the Catalogo of music which was to be stored in three cupboards (Schränke). A label for each score and/or set of parts was attached to each item. ${ }^{5}$ By 9 March 1765 the task was finalized, as a statement at the conclusion of the Catalogo confirmed: "Daß ich Endes benenter angemerckte Musicalien dieses Catalogi in meinem Beschluß habe, wird hiermit bescheiniget. Dreßden den 9. Martii 1765. Ioannes Georgius Schürer."

Composers listed in the Catalogo whose names suggest Italian origins are seen in the accompanying Appendix. Among them is a handful of Italians who had been employed in Dresden's Lutheran court church during the reign of Elector Johann Georg IV, August II's predecessor. Among those whose compositions suited Catholic worship are Vincenzo Albrici who served the Lutheran court church between 1656 and 1681; Carlo Fiorelli, a violinist of the same church who became a member of Dresden's Hofkapelle in 1709; Carlo Pallavicino; Carlo Luigi Pietragrua (Pietro Grua); Carlo Franco Pollarolo; "Paolo Seppi" (almost certainly an altist from the first choir of this Lutheran court chapel named Paolo Seppi, ${ }^{6}$ and Paul Sepp. ${ }^{7}$ ) The RISM entry for the manuscript parts of a "Beatus vir" setting by Giovanni Battista Vitali suggests that this work also might

Kirchen Music-Vorraths eine sauber geschriebene Copëy Ihrer Königl.[ichen] Hoheit der Churfürstin übergeben, weil Höchstdieselben alle übrige Music, welche sonst bey Ihro Maiest. [Majestät] der Höchstseeligen Königin gestanden, in höchst dero selbsteigenen Beschluß haben.” (I have presented a cleanly written copy of the recently compiled 2 Catalogis of the Elector's holdings of church music to Her Royal Highness, the Elector's wife, because Her Highness has at her very own disposal all remaining music that until now had been in the possession of Her Majesty, the late Queen). Sächsisches Staatsarchiv - Hauptstaatsarchiv Dresden (D-Dla), 10026 Geheimes Kabinett (Geh. Kab.), Loc. 910/1, 'Acta. Das Churfürstl: Orchestre und deßen Unterhaltung ingleichen. Das große Opern-Haus und andere zum Departement des Directeur des Plaisirs gehörige. Angelegenheiten betr. Anno [1711, 1717], 1764 [...] 68', ff. 82b-83a. (NB: this archive replaces r-v with a-b).

4 Maria Josepha acquired the musical estates of Dresden's concertmasters Jean-Baptiste Volumier and Johann Georg Pisendel, Kapellmeisters Johann Christoph Schmidt and Johann David Heinichen, and church composers Zelenka and Ristori. After her death, part of her library went to the church, part to Maria Antonia. FÜRSTENAU, Moritz. Zur Geschichte der Musik und des Theaters am Hofe zu Dresden (2 vols.) Dresden: Kuntze, 1861-1862. Repr. with commentary and indices by Wolfgang Reich, Leipzig: Edition Peters, 1971, vol. 1, p. 181.

5 Schürer's invoice is located in D-Dla, Geh. Kab., Loc. 910/1, 59a. Reproduced as Plate 1 in STOCKIGT, Janice B. Musica senza nome dell'autore: Anonymous works listed in the Music Catalogue of the Dresden Hofkirche, 1675. Studi Vivaldiani 2007, vol. 7, p. 25.

6 Fürstenau names this composer "Paolo Seppi" in FÜRSTENAU, op. cit., p. 157 and 254.

7 Eitner names this musician as "Sepp (Seppi), Paul, Altist an der Hofkapelle in Dresden ...” EITNER, Robert. Biographisch-bibliographisches Quellen-Lexikon der Musiker und Musikgelehrten der christlichen Zeitrechnung 
have come from Dresden's Lutheran court church. ${ }^{8}$

Sacred music collected during 1739-1740 when Saxon Prince Friedrich Christian (1722-1763) went on his Grand Tour, along with works dedicated to members of Saxony's ruling family, also came into the collection. The movement of music to the Hofkirche from Dresden's royal collection is demonstrated, for example, by entries into the incomplete catalogue of Maria Josepha of c. $1743 .{ }^{9}$ There, Masses for five vocal parts (SSATB) by the Neapolitan composers Francesco Feo, Francesco Nicola Fago ("detto Tarantino"), and Domenico Sarri, as well as a Requiem Mass by the Venetian composer Antonio Lotti are seen-works that by 1765 were listed in the Catalogo. Nevertheless, the principal contributions to the Hofkirche collection came from the musical estates of Zelenka, Ristori, and from the Venetian copying house of Baldan.

\section{Heinichen's contributions}

The great loss from Heinichen's music collection was explained in the 1849 by Moritz Fürstenau who reported that Heinichen's Nachlass, kept in a cupboard in Maria Josepha's apartments, was sold after her death in 1757 by a court Bettmeister (overseer of the court's household linen). ${ }^{10}$ Although funds later were made available to buy back missing items, and even though many Italian works from Heinichen's collection came to be retrieved, two Masses only by the Italian Angelo Antonio Caroli (1701-1778) were known to Schürer in $1765 .^{11}$

\section{Ristori's contributions}

Several Italian works seen in the Catalogo of 1765 came from the collection of the Italianborn Dresden composer Ristori who seems to have acquired sacred music in Naples when he travelled there after the marriage of Saxon Princess Maria Amalia to Charles, King of Naples and Sicily (1738). ${ }^{12}$ In fact, two streams of Neapolitan music are evident

bis zur Mitte des neunzehnten Jahrhunderts (10 vols.). Leipzig: Breitkopf \& Härtel, 1900-1904; repr. Graz: Akademische Druck, 1959, vol. 9, p. 142.

8 Sächsische Landesbibliothek - Staats- und Universitätsbibliothek (D-Dl), Mus.1875-D-1. RÉPERTOIRE INTERNATIONAL DES SOURCES MUSICALES. International Inventory of Musical Sources (RISM). [online]. URL: https:/ /opac.rism.info/search?id=212007280

9 Incomplete catalogue of Maria Josepha's music collection. D-Dl, Bibl. Arch. III Hb 787c.

10 FÜRSTENAU, Moritz. Beiträge zur Geschichte der königlich-sächsischen musikalischen Kapelle. Dresden: Meser, 1849, p. 144.

11 D-Dl, Mus. 2952-D-1,1-3; D-Dl, Mus. 2952-D-2.

12 Ristori's daughter Cecilia was in the entourage of the Maria Amalia, the new Queen of the Two Sicilies. 
in the Dresden collection: works that arrived via Bohemia between 1708 and $1738,{ }^{13}$ and those that appear to have been acquired between 1738 and $1740 .{ }^{14}$ Unfortunately no personal catalogue of Ristori's collection is known today, but many works that apparently come from his collection are in the hands of Neapolitan copyists. Moreover, his visit to Naples coincided with that of Prince Friedrich Christian who also was collecting music. Several items have a numbering system not found in known catalogues of Dresden: round paper stickers with numbers written in red ink glued to frontispieces of certain Italian manuscripts. These relate to an inventory of items the prince shipped from Rome to Dresden. ${ }^{15}$ This Neapolitan collection includes sacred works by Giovan Gualberto Brunetti, Emanuele Rincón de Astorga, Feo, Giuseppe Gonelli, Giovanni Battista Pergolesi, Luca Antonio Predieri, and Sarri. Today, two versions of these works sometimes exist in Dresden: the original Italian manuscript copy and a revised version to suit the Dresden Hofkapelle. The importance of Ristori in the Dresden reception of Neapolitan music has been clarified by Claudio Bacciagaluppi. ${ }^{16}$ Yet Ristori's collection also included works written on Venetian paper, or else by composers known to have come from Venice. These include Mass settings by Agostino Tinazzoli (named Finazolli by Schürer), Lotti, Giovanni Porta, and a "Beatus vir" by Pietragrua, a copy identified by Jóhannes Ágústsson to be in the hand of Antonio Vivaldi's father, Giovanni Battista. ${ }^{17}$ When Italian works from the collection of Ristori are considered together with his own numerous sacred compositions (sadly, most of his sacred works are missing), it is clear that he was a major contributor of music to the collection of Dresden's Hofkirche.

\section{Zelenka's contributions}

The other principal contributor to Dresden's sacred music collection was Zelenka who either composed or collected more than 200 of the 800 plus works seen in the Catalogo. Fortunately, his personal Inventarium of church music collection exists today. ${ }^{18}$ I have proposed that Zelenka used at least two codes in the Inventarium to identify the source of Masses and Vespers music he possessed, works that almost certainly were acquired in exchange for his own compositions. The codes are seen only with Mass and Vespers

13 BACCIAGALUPPI, Claudio - STOCKIGT, Janice B. Italian Manuscripts of Sacred Music in Dresden: The Neapolitan Collection of 1738-1740. Fonti Musicali Italiane, 2010, vol. 15, Table 4, p. 161-162.

14 Ibid., Table 7, p. 164-166.

15 Scores of sacred music numbered in red ink on round stickers are identified in BACCIAGALUPPI STOCKIGT, op. cit., p. 152; Table 5, p. 163.

16 BaCCIAGaluPPI, Claudio, Rom, Prag, Dresden: Pergolesi und die Neapolitanische Messe in Europa. Kassel: Bärenreiter, 2010, p. 171-75. Also, ÁGÚSTSSON, Jóhannes. Giovanni Alberto Ristori at the Court of Naples 1738-1740 in Studi pergolesiani - Pergolesi studies, vol. 8. Editors C. Bacciagaluppi - H.-G. Ottenberg - L. Zoppelli (eds.). Bern: Peter Lang, 2012, p. 53-100.

17 TALBOT, Michael. Miscellany. Studi Vivaldiani, 2015, vol. 15, p. 183-184.

18 Inventarium rerum Musicarum Ecclesiae servientium. MS. D-Dl, Bibl. -Arch. III H b 787d. http://digital. slub-dresden.de/id425379515 
psalm listings, and they were used only between 1726 and 1730 or 1731, those years during which Zelenka amassed the greater part of his collection. ${ }^{19}$ It is known that he exchanged compositions with Florian Burian, the regens chori of the Cistercian monastery at Osek $\left(\right.$ Ossegg) in Northern Bohemia. ${ }^{20}$ These exchanges are indicated with the underlined letters "Oss", ${ }^{21}$ sometimes by the letter "O", as seen with the Inventarium entry of a "Magnificat" by Vivaldi (RV 610) now held in Prague. ${ }^{22}$ While its cover states that the work belonged to Florian Burian, the title and Vivaldi's name are in Zelenka's hand. ${ }^{23}$ Italian composers whose compositions Zelenka marked with the letters "Oss" or "O" include Giuseppe Antonio Vincenzo Aldrovandini, Antonio Bioni, Giovanni Battista Borri, Antonio Caldara, Domenico Gabrielli, Antonio Negri (assigned to Luigi Negri by Schürer), and Vivaldi.

Zelenka also used the letter "P" to indicate the source of certain items. This letter might indicate a place (Prague?), an institution, or a person. A great many entries accompanied by this letter have concordances either in the collections of Prague's Metropoli$\tan$ Cathedral, ${ }^{24}$ or the Kreuzherren Order. ${ }^{25}$ It is possible that "P" indicates Franz Poppe (d.1730), the regens chori of St Francis Serafin (the Kreuzherren's church in Prague), or it might indicate someone from the Metropolitan Cathedral, Music Director Carl Christoph Gayer, for example. Zelenka's dependence upon sources identified by this letter is especially notable in his collection of Vespers psalms. Italian composers accompanied by the letter "P" in the Inventarium include Aldrovandini, Caldara, Carlo Cozzi, Francesco Durante, Carlo Foschi, Tommaso Antonio Ingegneri, Lotti, Francesco Mancini, "Novari" (Jan František Novák), Giuseppe Ottavio Pitoni, Sarri, and Padre Urio.

False attributions exist among Zelenka's collection. These include the naming of Bioni as composer of a mass now identified as a work by Johann Melchior Pichler $;{ }^{26}$ Cozzi

19 STOCKIGT, Janice B. Transmission of sacred music between Bohemia and Dresden as seen in the collection of Jan Dismas Zelenka (1679-1745). Sammeln - Musizieren - Forschen. Zur Dresdner höfischen Musik des 18. Jahrhunderts, Music Department of the Saxon State and University Library Dresden (SLUB): January 21-23, 2016. Forthcoming.

20 VOJTĚŠKOVÁ, Jana. Die Zelenka-Überlieferung in Böhmen und in der Tschechoslowakei. In Zelenka-Studien I: Referate der Internationalen Fachkonferenz Jan Dismas Zelenka (1679-1745), Marburg, J.-G.-Herder-Institut, 16.-20. November 1991. Thomas Kohlhase (ed.). Musik des Ostens 14. Kassel \& New York: Bärenreiter, 1993, p. 95 .

21 Most masses in the Inventarium with the letters 'Oss' also are found both in Florian Burian's non-thematic catalogue and Osek's thematic catalogue which began to be compiled in 1753/4.

22 Catalogus Musicaliorum. Anno 1720, in Ordinem digestus ab codem à quo et Anno 1733 est renovates. CZ-Pnm, XXXIII-B-55.

23 STOCKIGT, Janice B. Musica senza nome dell'autore: Anonymous Works listed in the Music Catalogue of the Dresden Hofkirche, 1675. Studi Vivaldiani 2007, vol. 7, p. 10-11.

24 ŠTEFAN, Jiří. Ecclesia Metropolitana Pragensis Catalogus Collectionis Operum Artis Musicae, (2 vols.). Catalogus Artis Musicae in Bohemia et Moravia Cultae: Artis Musicae Antiquioris Catalogorum Series 4. Prague: Supraphon, 1992.

25 FUKAČ, Jiří. Kř̌žovnický hudebni inventář: Př́spěvek k poznáni křrižovnické hudebni kultury a jejiho mista v hudebnim životě barokni Prahy (2 vols). Ph. D. thesis, Brno, 1959.

26 D-Dl, Mus. 2498-D-1. ÁGÚSTSSON, Jóhannes. Joseph Johann Adam of Liechtenstein - Patron of Vivaldi, Studi vivaldiani, vol. 17, 2017, p. 3-78. 
as composer of a "Beatus vir" setting; ${ }^{27}$ Annibale Pio Fabri as composer of a Vesperae de Confessore (without Magnificat)-works attributed to at least five different composers in numerous locations; ${ }^{28}$ Foschi as composer of a "Laetatus sum" setting by Pietragrua; ${ }^{29}$ Luigi Negri as composer of works probably by Antonio Negri. ${ }^{30}$ The many compositions Zelenka attributed to "Novari" hide the identity of Jan František Novák, a musician from Prague's Metropolitan Cathedral. ${ }^{31}$

Perhaps these deceptions are related to a condition of the well-known 1717 purchase by Prague's Metropolitan Cathedral of part of Baltazar Knapp's extensive collection of sacred music from Rome and Naples. The Provost of the Cathedral, Daniel Joseph Mayer, insisted that the Cathedral's music director Gayer would ensure no losses to the collection, nor should the music make its way into other hands by being copied. ${ }^{32}$ When items from Zelenka's sacred music collection are counted together with his own compositions, his contributions to the repertoire of sacred Catholic music of Dresden place him alongside Ristori.

\section{The Collection from the copying house of Iseppo Baldan}

Listed into the Catalogo of 1765 is a large suite of sacred music supplied by the Venetian copying house of Iseppo Baldan whose florid hand is seen on many title pages. Most items are attributed to Baldassare Galuppi "detto Buranello". Today, several works are missing from this collection that originally comprised about 85 compositions, mostly as scores in octavo format or as sets of parts. ${ }^{33}$ It is not clear if all works were sent at the same time, or whether they came in batches. The Catalogo of 1765 shows that performance materials often accompanied the scores, but these now are missing. The collection includes Masses (usually comprising Kyrie, Gloria, Credo), Requiems, Ambrosian

27 D-Dl, Mus. 1487-E-1. This setting probably was composed by Antonio Negri.

28 D-Dl, Mus. 2720-E-1,1-5. Information kindly communicated by Michael Driscoll.

29 POPPE, Gerhard. Kontinuität des Repertoires? Einige Bemerkungen zur Kirchenmusik am Dresdner Hof zwischen 1697 und 1717. In Miscellaneorum de Musica Concentus: Karl Heller zum 65. Geburtstag am 10. Dezember 2000. Walpurga Alexander - Joachim Stange-Elbe - Andreas Waczkat (eds.). Rostock: Universität Rostock, 2000 , p. 78.

30 Zelenka's cover title to a "Laudate pueri” setting attributed by Schürer to Luigi Negri reads: Laudate pueri Dominu[m] a 3 | C: A: B: | VViolin 2 | Viola | e | Basso Conti | del | S: Antonio Negri. D-Dl Mus. $2883-D-1$. Zelenka's copy of a "Beatus vir" setting attributed to Luigi Negri (D-Dl, Mus. 2883-D-2) probably was composed by Antonio Negri.

31 The Bohemian composer Jan František Novák (1706-1771) was listed by Zelenka as anonymous ("Anonymi”; “N. N.”), or "Novari”. Novák succeeded Antonín Görbig in 1737 as choral director of of St Vitus, Prague’s Metropolitan Cathedral, a position he retained until 1758. The Catalogo also names 'Noack' as composer of three works by Novák. KOSTÍLKOVÁ, Marie. An Outline of the History of the St. Vitus' Music Choir. In ŠTEFAN, Jiří, op. cit., vol. 1, p. 95.

32 Ibid., p. 93.

33 This collection was investigated by BURDE, Ines. Die venezianische Kirchenmusik von Baldassare Galuppi. Frankfurt am Main: Peter Lang, 2008. 
hymns, sacred motets, Marian antiphons, and music for Holy Week, Vespers, and Compline. Three styles of sacred music-a cappella, "Ordinary", Solemn ${ }^{34}$-are used throughout this collection, which, except for Litanies, would meet all musical needs of a royal Catholic chapel. Apart from works ascribed to Galuppi, composers whose music also was supplied by Baldan include items attributed to Giuseppe Chiesa, Vincenzo Ciampi, Johann Adolf Hasse, Niccolò Jommelli, Giovanni Battista Pescetti, Antonio Puppi (a student of Galuppi), and Johann Gottfried Schwanenberg.

Most scores are protected with a blue-grey cover (Umschlag) to which between one and three labels are attached, the originals being of varying shapes, as seen in Exx. 1 and 2. These labels are not associated with those prepared for the Catalogo of 1765, ${ }^{35}$ nor for a later catalogue of circa $1784 .{ }^{36}$ Covers and labels such as these also are seen in secular items supplied by Baldan.

Above certain original labels of Baldan's consignment Schürer wrote storage information (see Ex. 2). An incipit sometimes is given. Numbers to agree Catalogo entries of 1765 are in the hand of the Dresden court copyist Carl Gottlob Uhle. Many original labels are obliterated by another that was prepared in 1765 to agree with the Catalogo listing made under Schürer's direction (see Ex. 3). Most, however, were covered with label prepared in c.1784 (see Ex. 4).

The last dated works of the collection from Baldan are two compositions by Ciampi: "Messe solenne", a source Schürer catalogued in 1765 now kept in Berlin, ${ }^{37}$ and a "Te Deum laudamus" held in Dresden. ${ }^{38}$ The title page of each includes the date: "21 7bre [September] 1758:"

Who was the patron to instigate this body of music? The date "21 7bre 1758" provides a terminus ante quem for this supply. Perhaps it also hints as to how and why this corpus of music came into the court's possession during a chaotic period of Dresden's history. Two years earlier, in 1756 at the outset of the Third Silesian War, August III was banished to Warsaw by Frederick II following the defeat by Prussian forces of Saxon troops. Saxony then became a battleground. On 17 November 1757, Maria Josepha died in Dresden. Among such turmoil it is unlikely that a quantity of music would have been ordered for Dresden's Hofkirche. Besides which, on 19 September 1759, all younger members of the Saxon electoral family left for Munich in anticipation of battles to be fought in Dresden between Prussia and Austria.

A hint concerning the patron's identity is seen on original labels of a "Kyrie e Gloria" by Pescetti, ${ }^{39}$ and on each label of a "Kyrie, Gloria e Credo" in three volumes by

34 RIEDEL, Friedrich W. Kirchenmusik am Hofe Karls VI: (1711-1740). Munich \& Salzburg: Katzbichler, 1977 , p. 67.

35 RISM entries identify the copyists of labels shown in Exx. 1-2 as S-Dl-056.

36 Catalogo della Musica di Chiesa, composta da diversi Autori secondo l'alfabetto [sic]. Armaro IIIzo, principiando dalla littera S sino al Z con l'aggiunta degl'Autori senza Nome, 3 vols. Vols. 1 and 2 missing. D-Dl, Sign. Bibl. Arch. III H 788, 3. http://digital.slub-dresden.de/id425373169

37 D-B, Mus. ms. 3609.

38 D-Dl, Mus. 3059-E-1.

39 D-Dl, Mus. 2967-D-1,1-2. 


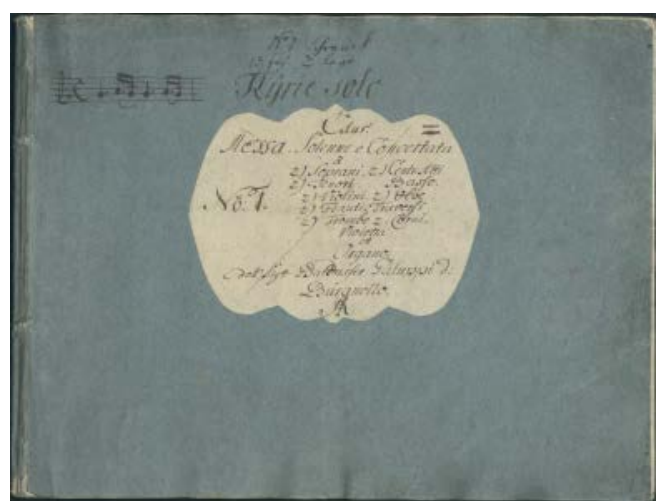

Ex. 1 Baldassare Galuppi. Messe: No. 1. Kyrie, Gloria e Credo. Storage in hand of Schürer; Incipit in hand of Uhle; Cover label (vol. 1): copyist S-DL-056 (RISM); "No: 1" hand of Uhle; D-DI, Mus. 2973-D-3. Original and reproduction:

All rights reserved (c) http://digital.slub-dresden. de/fileadmin/data/426029410/426029410_tif/ jpegs/426029410.pdf

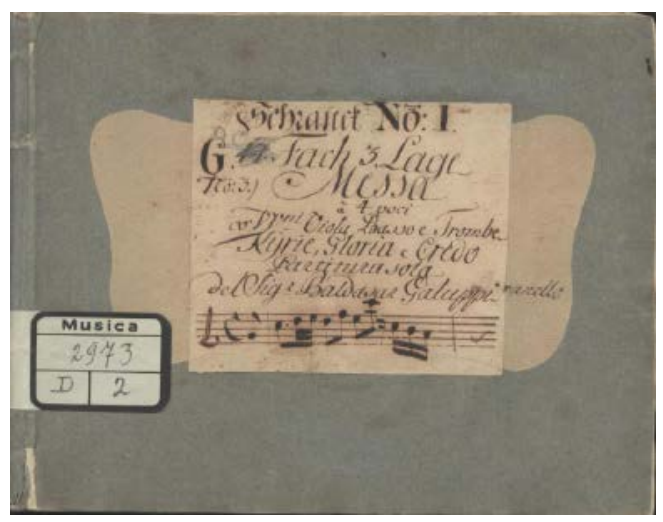

Ex. 3 Baldassare Galuppi. Messe, Partiture sole: No. 3. Kyrie, Gloria e Credo. Cover label (1765) hand of Carl Gottlob Uhle; D-Dl, Mus. 2973-D-2. Original and reproduction:

All rights reserved (๑) http://digital.slub-dresden. de/fileadmin/data/426200810/426200810_tif/ jpegs/426200810.pdf

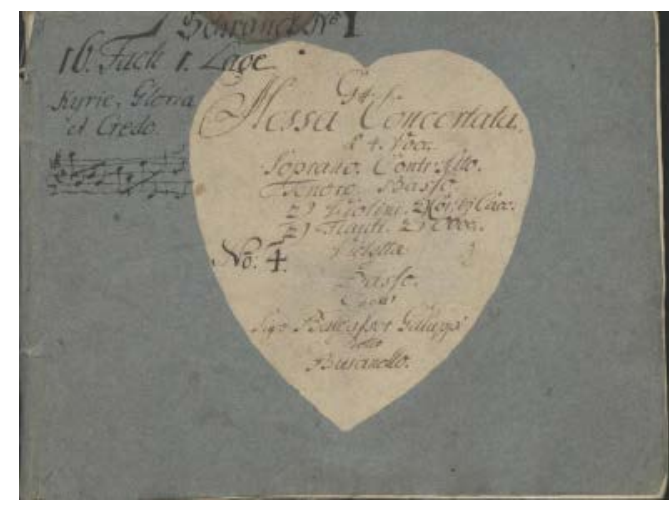

Ex. 2 Baldassare Galuppi. Messe: No. 4. Kyrie, Gloria e Credo. Storage (and incipit?) in hand of Schürer; Cover label: copyist S-DL-056 (RISM); "No: 4" hand of Uhle;

D-DI, Mus. 2973-D-7. Original and reproduction:

All rights reserved (c)

http://digital.slub-dresden.de/fileadmin/ data/426221583/426221583_tif/jpegs/426221583.pdf

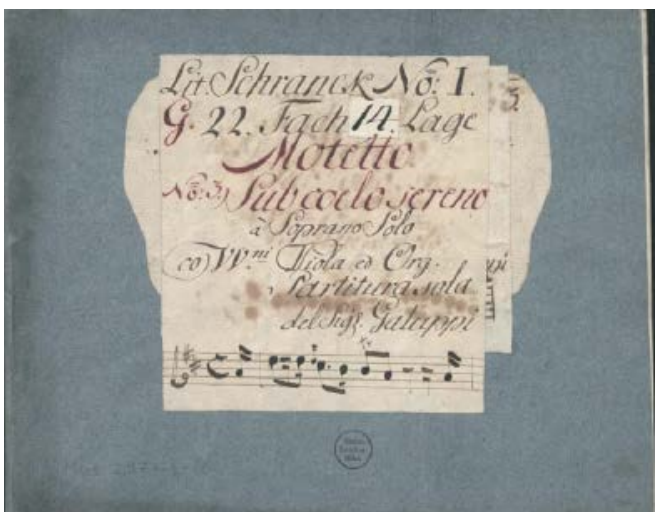

Ex. 4 Baldassare Galuppi. Motetti, Partiture sole: "Sub coelo sereno". Cover label (c.1784) hand of Carl Gottlob Uhle; D-DI, Mus. 2973-E-18. Original and reproduction:

All rights reserved (c) http://digital.slub-dresden. de/fileadmin/data/426601394/426601394_tif/ jpegs/426601394.pdf

Galuppi where the monogram "AR"-Augustus Rex-is written as seen in Ex. 1. Despite initial suppositions that Baldan's collection of sacred music was intended for Dresden, the possibility exists that it was ordered for August III in Warsaw where the augmented 
Polish Kapelle served the music-loving monarch during exile. ${ }^{40}$ By 1762 this small travelling orchestra established by August II had grown to twenty-nine musicians, including four singers, plus additional vocalists from Dresden and the copyist Uhle, assisted by two "Schreibschüler" (copyists in training).$^{41}$ During this time of exile members of Count Brühl's ensemble also could be called upon to join with the Polish Kapelle. After the Peace of Hubertusburg (15 February 1763) and the return of August III to Saxony, music must have been among royal possessions brought back to Dresden and integrated into collections of the court. Thus, by 1765 sacred works by the Italians Antonio Duni (onetime Kapellmeister of the Polish Kapelle), and Mattia Gerardi (who assisted the music of August III's Polish court) came into the repertoire of Dresden's Hofkirche.

The many false attributions in Baldan's collection now in Dresden reveal the deceit of the Venetian supplier. Among works attributed to Galuppi are compositions identified as being written by Ferdinando Bertoni, Gioacchino Cocchi, Florian Gassmann, Hasse, Jommelli, and Lotti. ${ }^{42}$ Moreover, five psalm settings by Vivaldi have been recognized within the collection, ${ }^{43}$ the most recent being Michael Talbot's discovery of a setting of "Laetatus sum". ${ }^{44}$ It is notable that at least one of Baldan's copyists was Vivaldi's nephews, Carlo. ${ }^{45}$

From Dresden, much of the Italian sacred music collected by Zelenka, Heinichen, and Ristori then spread further afield. Bach, for example, had copies of Dresden sources of music by Palestrina, ${ }^{46}$ Pergolesi, ${ }^{47}$ and Caldara. ${ }^{48}$ Although unlisted by Schürer, a "Magnificat" setting by Caldara that once belonged to Heinichen was copied by Bach in the

40 Research on this possibility now is being undertaken by Jóhannes Ágústsson.

41 ŻÓRAWSKA-WITKOWSKA, Alina. The Saxon Court of the Kingdom of Poland. In Music at German Courts, 1715-1760: Changing Artistic Priorities. Samantha Owens -Barbara M. Reul - Janice B. Stockigt (eds.). Woodbridge: Boydell Press, 2011, p. 51-77 at p. 70-71.

42 BURDE, op. cit., and RISM entries.

43 The psalms are "Dixit Dominus" (RV 807); "Beatus vir" (RV 597); "Nisi Dominus" (RV 803); "Lauda Jerusalem" (anonymous setting revised by Vivaldi: RV Anh. 35a). These are discussed in TALBOT, Michael. Recovering Vivaldi’s Lost Psalm. Eighteenth-Century Music, 2004, vol. 1, p. 61-77. Also, STOCKIGT, Janice B. TALBOT, Michael. Two More Vivaldi Finds in Dresden. Eighteenth-Century Music, 2006, vol. 3, p. 35-61.

44 TALBOT, Michael. Another Vivaldi work falsely attributed to Galuppi by Iseppo Baldan: A new Laetatus sum for choir and strings in Dresden. Studi Vivaldiani, 2017, vol. 17, p. 103-119.

45 TAlBOT, Michael. The Vivaldi Compendium. Woodbridge: Boydell, 2011, p. 30.

46 Palestrina's Missa sine nomine was copied by J. S. Bach, c.1742. BEIßWENGER, Kirsten. Johann Sebastian Bachs Notenbibliothek. Kassel \& New York: Barenreiter, 1992. I/P/2, p. 305-306. RÉPERTOIRE INTERNATIONAL DES SOURCES MUSICALES. International Inventory of Musical Sources (RISM). [online]. URL: 〈https:// opac.rism.info/search?id=212009443> BEISSWENGER, op. cit., I/P/2, p. 305-306.

47 Ibid., II/P/3, p. 367-68. Pergolesi's Stabat Mater was reworked c.1745/1747 by Bach as Tilge, Höchster, meine Sünden, Cantata BWV 1083.

48 I am very grateful to Bruno Musumeci who communicated that he has identified J. S. Bach's apocryphal Sanctus setting (BWV 239) as being based upon the opening of the Gloria of Zelenka's reworking of Caldara's Mass, Missa Providentiae (D-Dl, Mus. 2170-D-7). WOLLNY, Peter. Zur Identifizierung einiger anonym überlieferter liturgischer Werke aus Johann Sebastian Bachs Notenbibliothek. Bach-Jahrbuch, 2017, p. 43-87. 
early $1740 \mathrm{~s},{ }^{49}$ a copy now kept in Berlin. ${ }^{50}$ After the death in 1756 of Gottlob Harrer (Zelenka's student and Bach's successor) his extensive music collection became available through the firm of Breitkopf. In the nineteenth century Berlin collectors such as Georg Poelchau acquired from Dresden examples of music, including the Catalogo of 1765. Tracing the spread from Italy to Dresden of music, often via Bohemian religious institutions, is nowhere yet complete. This movement northwards to German centres such as Leipzig and Berlin will be a task for those with an interest in the dispersal of a rich and varied repertoire of sacred music by Italian composers.

\section{Bibliography}

\section{Primary Sources}

Catalogo (Thematico) [sic] della Musica di Chiesa (catholica [sic] in Dresda) composta Da diversi Autori - secondo l'Alfabetto 1765, D-B, Mus. ms. theor. Kat. 186. http://resolver.staatsbibliothek-berlin.de/SBB0001A38800000000

Catalogo della Musica di Chiesa, composta da diversi Autori secondo l'alfabetto [sic]. Armaro IIIzo, principiando dalla littera $\mathrm{S}$ sino al Z con l'aggiunta degl'Autori senza Nome, 3 vols. Vols. 1 and 2 missing. Ms. D-Dl, Sign. Bibl. Arch. III H 788, 3. http://digital.slub-dresden.de/ id425373169

Catalogus Musicaliorum. Anno 1720, in Ordinem digestus ab codem à quo et Anno 1733 est renovatus. (A non-thematic catalogue begun in 1720 by the regens chori atthe Cistercian monastery at Osek, Florian Burian. Continued 1723-33). CZ-Pnm 65/52.

Catalogus Musicalium pro Chorò Ossecénsi'. (A thematic catalogue begun 1753-4 by the regens chori at the Cistercian monastery at Osek, P. Nivard Sommer, and continued by several other scribes). CZ-Pnm 65/52.

Inventarium rerum Musicarum Ecclesiae servientium (Zelenka's inventory). MS. D-Dl Bibl. -Arch. III H b 787d. Repr. Zelenka-Dokumentation, 169-218.

http://digital.slub-dresden.de/id425379515

Incomplete catalogue of the music collection of Maria Josepha. D-Dl Bibl. Arch. III Hb 787

D-Dla, 10026 Geheimes Kabinett, Loc. 910/1, 'Acta. Das Churfürstl: Orchestre und deßen Unterhaltung ingleichen. Das große Opern-Haus und andere zum Departement des Directeur des Plaisirs gehörige. Angelegenheiten betr. Anno [1711, 1717], 1764 [...] 68', f. 82b-83a [right column]. (NB: this archive replaces $r-v$ with $a-b)$.

49 D-Dl, Mus. 2170-D-2,3. BEIßWENGER, op. cit., I/C/1, p. 277-278.

50 D-B, Mus.ms. 2755 (1). 


\section{Archives}

Staatsbibliothek zu Berlin - Preußischer Kulturbesitz, Musikabteilung. (D-B)

Sächsische Landesbibliothek - Staats- und Universitätsbibliothek Dresden. (D-Dl)

Sächsisches Staatsarchiv - Hauptstaatsarchiv Dresden. (D-Dla)

Muzeum české hudby, hudebně historické oddělení (Museum of Czech Music, Historical Department). (CZ-Pnm)

\section{Literature}

ÁGÚSTSSON, Jóhannes. Giovanni Alberto Ristori at the Court of Naples 1738-1740. In Studi pergolesiani - Pergolesi studies, vol. 8. Editors C. Bacciagaluppi - H.-G. Ottenberg - L. Zoppelli (eds.). Bern: Peter Lang, 2012, p. 53-100.

ÁGÚSTSSON, Jóhannes. Joseph Johann Adam of Liechtenstein - Patron of Vivaldi, Studi vivaldiani, vol. 17, 2017, p. 3-78.

BACCIAGAluPPI, Claudio. Rom, Prag, Dresden: Pergolesi und die Neapolitanische Messe in Europa. Kassel: Bärenreiter, 2010.

BACCIAGALUPPI, Claudio - STOCKIGT, Janice B. Italian Manuscripts of Sacred Music in Dresden: The Neapolitan Collection of 1738-1740. Fonti Musicali Italiane, 2010, vol. 15, p. 141-197.

BEIßWENGER, Kirsten. Johann Sebastian Bachs Notenbibliothek. Kassel \& New York: Barenreiter, 1992.

BURDE, Ines. Die venezianische Kirchenmusik von Baldassare Galuppi. Frankfurt am Main: Peter Lang, 2008.

EITNER, Robert. Biographisch-bibliographisches Quellen-Lexikon der Musiker und Musikgelehrten der christlichen Zeitrechnung bis zur Mitte des neunzehnten Jahrhunderts (10 vols.). Leipzig: Breitkopf \& Härtel, 1900-1904; repr. Graz: Akademische Druck, 1959.

FUKAČ, Jiří. Křižovnický hudebni inventár: Přispěvek $k$ poznáni křižovnické hudebni kultury a jejiho mista v hudebnim životě barokni Prahy (2 vols). Ph. D. thesis, Brno, 1959.

FÜRSTENAU, Moritz. Zur Geschichte der Musik und des Theaters am Hofe zu Dresden (2 vols.) Dresden: Kuntze, 1861-1862. Repr. with commentary and indices by Wolfgang Reich, Leipzig: Edition Peters, 1971.

FÜRSTENAU, Moritz. Beiträge zur Geschichte der königlich-sächsischen musikalischen Kapelle. Dresden: Meser, 1849.

KOSTÍlKOVÁ, Marie. An Outline of the History of the St. Vitus' Music Choir. In Ecclesia Metropolitana Pragensis Catalogus Collectionis Operum Artis Musicae. Jiř́i Stefan (ed.). Catalogus Artis Musicae in Bohemia et Moravia Cultae: Artis Musicae Antiquioris Catalogorum. Series 4. vol. 1. Prague: Supraphon, 1992, p. 79-101.

POPPE, Gerhard. Kontinuität des Repertoires? Einige Bemerkungen zur Kirchenmusik am Dresdner Hof zwischen 1697 und 1717. In Miscellaneorum de Musica Concentus: Karl Heller zum 65. Geburtstag am 10. Dezember 2000. Walpurga Alexander- Joachim Stange-Elbe - Andreas Waczkat (eds.). Rostock: Universität Rostock, 2000. p. 49-81.

RIEDEL, Friedrich W. Kirchenmusik am Hofe Karls VI: (1711-1740). Munich \& Salzburg: Katzbichler, 1977.

RÉPERTOIRE INTERNATIONAL DES SOURCES MUSICALES. International Inventory of Musical Sources (RISM). [online]. URL: 〈https://opac.rism.info> 
ŠTEFAN, Jiří. Ecclesia Metropolitana Pragensis Catalogus Collectionis Operum Artis Musicae, (2 vols.). Catalogus Artis Musicae in Bohemia et Moravia Cultae: Artis Musicae Antiquioris Catalogorum Series 4. Prague: Supraphon, 1992.

STOCKIGT, Janice B. Musica senza nome dell'autore: Anonymous works listed in the Music Catalogue of the Dresden Hofkirche, 1675. Studi Vivaldiani 2007, vol. 7, p. 3-52.

STOCKIGT, Janice B. Transmission of sacred music between Bohemia and Dresden as seen in the collection of Jan Dismas Zelenka (1679-1745). Sammeln - Musizieren - Forschen. Zur Dresdner höfischen Musik des 18. Jahrhunderts, Music Department of the Saxon State and University Library Dresden (SLUB): January 21-23, 2016. Forthcoming.

STOCKIGT, Janice B. - TALBOT, Michael. Two More Vivaldi Finds in Dresden. Eighteenth-Century Music, 2006, vol. 3, p. 35-61.

TALBOT, Michael. Miscellany. Studi Vivaldiani, 2015, vol. 15, p. 183-184.

TALBOT, Michael. Recovering Vivaldi’s Lost Psalm. Eighteenth-Century Music, 2004, vol. 1, p. 61-77.

TALBOT, Michael. The Vivaldi Compendium. Woodbridge: Boydell, 2011.

TALBOT, Michael. Another Vivaldi work falsely attributed to Galuppi by Iseppo Baldan: A new Laetatus sum for choir and strings in Dresden. Studi Vivaldiani, 2017, vol. 17, p. 103-119.

VOJTĚŠKOVÁ, Jana. Die Zelenka-Überlieferung in Böhmen und in der Tschechoslowakei. In Zelenka-Studien I: Referate der Internationalen Fachkonferenz Jan Dismas Zelenka (1679-1745), Marburg, J.-G.-Herder-Institut, 16.-20. November 1991. Thomas Kohlhase (ed.). Musik des Ostens 14. Kassel \& New York: Bärenreiter, 1993, p. 85-108.

WOLLNY, Peter. Zur Identifizierung einiger anonym überlieferter liturgischer Werke aus Johann Sebastian Bachs Notenbibliothek. Bach-Jahrbuch, 2017, p. 43-87.

ŻÓRAWSKA-WITKOWSKA, Alina. The Saxon Court of the Kingdom of Poland. In Music at German Courts, 1715-1760: Changing Artistic Priorities. Samantha Owens -Barbara M. Reul - Janice B. Stockigt (eds.). Woodbridge: Boydell Press, 2011, p. 51-77. 


\section{Appendix}

Italian composers listed in the Catalogo compiled by Johann Georg Schürer (1765)

\begin{tabular}{|c|c|c|c|}
\hline Name & Dates & Source & D-DI Mus. \\
\hline Albinoni, Tomaso Giovanni & $1671-1751$ & Unknown & $2199-$ \\
\hline Albrici, Vincenzo & $1631-1696$ & \begin{tabular}{|l|}
$\begin{array}{l}\text { Lutheran court chapel } \\
\text { (Dresden) }\end{array}$ \\
\end{tabular} & $1821-$ \\
\hline Aldrovandini, Giuseppe Antonio Vincenzo & 1671-1707 & \begin{tabular}{|l|} 
Zelenka \\
\end{tabular} & $2204-$ \\
\hline Allegri, Gregorio & $1582-1652$ & Zelenka & $2-$ \\
\hline Ariosti, Attilio & $1666-1729$ & Zelenka & $2156-$ \\
\hline Baliani, Carlo & c. $1680-1747$ & Zelenka & $2243-$ \\
\hline "Bassani, Giovanni Battista ${ }^{51}$ & c. $1650-1715$ & $\begin{array}{l}\text { Catholic court church } \\
\text { (Dresden)? }\end{array}$ & $2114-$ \\
\hline "Bel[I]inzani, Paolo Benedetto & c.1690-1757 & $\begin{array}{l}\text { Catholic court church } \\
\text { (Dresden)? }\end{array}$ & $2431-$ \\
\hline Benevoli, Orazio & $1605-1672$ & Zelenka & $1705-$ \\
\hline Bioni, Antonio (incorrect attribution) $)^{52}$ & c.1669-post 1739 & Zelenka & $2498-$ \\
\hline Borri, Giovanni Battista & fl. 1665-1688 & Zelenka & $2059-$ \\
\hline Brunetti, Giovan Gualberto & $1706-1787$ & Ristori? & 4387- \\
\hline Caldara, Antonio & c. $1671-1736$ & Zelenka & $2170-$ \\
\hline Canta [=Giovanni Giuseppe Cantù] & c. $1688-1739$ & \begin{tabular}{|l|} 
Ristori? \\
\end{tabular} & $4975-$ \\
\hline *Cantoni (See Vanini, Elia) & & \begin{tabular}{|l|} 
Catholic court church \\
(Dresden)?
\end{tabular} & \\
\hline Capelli, Giovanni Maria & c. $1648-1726$ & Italian scores & $2244-$ \\
\hline Caroli, Angelo Antonio & $1701-1778$ & Heinichen & $2952-$ \\
\hline Casselli, Vincenzo & fl. mid $18^{\text {th }} \mathrm{c}$. & Italian scores & $2366-$ \\
\hline Chiesa, Melchiorre & $1716-1782$ & Italian score & $3283-$ \\
\hline Chiesa, Giuseppe $^{53}$ & $?$ & Iseppo Baldan & $3283-$ \\
\hline Ciampi, Vincenzo & $1719-1762$ & Iseppo Baldan & $3059^{54}$ \\
\hline *Colonna, Giovanni Paolo & $1637-1695$ & $\begin{array}{l}\text { Catholic court church } \\
\text { (Dresden)? }\end{array}$ & 1807- \\
\hline Conti, Francesco Bartolomeo & $1681 / 2-1732$ & Zelenka & $2190-$ \\
\hline \multicolumn{4}{|l|}{ Contini [=Francesco Conti] } \\
\hline $\begin{array}{l}\text { Corbisieri, Francesco (c1733-post 1802)? Or } \\
\text { Antonio (1720-1790) }\end{array}$ & c. 1733 -post 1802 & Unknown & $2869-$ \\
\hline Cozzi, Carlo (incorrect attribution) ${ }^{55}$ & † c. 1658 & Zelenka & 1487- \\
\hline
\end{tabular}

51 Asterisks indicate publications.

52 Jóhannes Ágústsson has identified this Mass as being composed by Johann Melchior Pichler. See ÁGÚSTS-

SON, Jóhannes. Joseph Johann Adam - Patron of Vivaldi. Studi vivaldiani, 2017, vol. 17, p. 3-78.

53 Named Giuseppe Chiesa by Iseppo Baldan.

54 The Dresden source of Baldan's copy of Ciampi's Messe Solenne today is held in Berlin: D-B, Mus. ms. 3609.

55 Perhaps composed by Antonio Negri. 
Italian Sacred Music listed in the Catalogue of Dresden's Catholic Court Church, 1765

\begin{tabular}{|c|c|c|c|}
\hline Name & Dates & Source & D-DI Mus. \\
\hline de Astorga Emanuele Rincón & $1680-1757 ?$ & \begin{tabular}{|l|} 
Royal collection \\
Revised by Ristori \\
\end{tabular} & $2360-$ \\
\hline Duni, Antonio & 1700 -post 1766 & Warsaw court? & $3154-$ \\
\hline Durante, Francesco & $1684-1755$ & Zelenka & 2397- \\
\hline Fabri, Annibale Pio (incorrect attribution) ${ }^{56}$ & $1697-1760$ & Zelenka & $2720-$ \\
\hline Feo, Francesco & $1691-1761$ & $\begin{array}{l}\text { Maria Josepha's col- } \\
\text { lection }\end{array}$ & 2409- \\
\hline Finazolli [= Agostino Tinazolli] & fl. early 1700 s & Ristori & 2870 \\
\hline Fiorelli, [Carlo?] & d.1711? & \begin{tabular}{|l|} 
Lutheran court chapel \\
(Dresden)
\end{tabular} & 2370 \\
\hline Foschi, Carlo (incorrect attribution) ${ }^{57}$ & c1665-1726 & Zelenka & $1900-$ \\
\hline Gabrielli, Domenico & $1659-1690$ & Zelenka & $2120-$ \\
\hline Galuppi, Baldassare ["Buranello"] ${ }^{58}$ & $1706-1785$ & Baldan & \\
\hline Gasparini, Francesco & $1661-1727$ & \begin{tabular}{|l|} 
Pisendel \\
Ristori \\
\end{tabular} & $2163-$ \\
\hline Gerardi, Mattia & fl. mid 1700s & $\begin{array}{l}\text { Warsaw and Dresden } \\
\text { courts }\end{array}$ & $2060-$ \\
\hline *Gianettini, Antonio & $1648-1721$ & Jesuits? & $1860-$ \\
\hline Gonelli, Giuseppe & c. $1685-1745$ & \begin{tabular}{|l|} 
Royal collection \\
Zelenka \\
\end{tabular} & $2735-$ \\
\hline Ingegneri, Tommaso Antonio & c. $1671-1726$ & Zelenka & 1131- \\
\hline Jommelli, Niccolò & $1714-1774$ & Baldan & $3032-$ \\
\hline Leo, Leonardo & $1694-1744$ & \begin{tabular}{|l|} 
Royal collection \\
Ristori
\end{tabular} & $2460-$ \\
\hline "Lorenzani, Paolo & $1640-1713$ & $\begin{array}{l}\text { Catholic court church } \\
\text { (Dresden)? }\end{array}$ & $2021-$ \\
\hline Lotti, Antonio & & \begin{tabular}{|l|} 
Royal collection Ze- \\
lenka \\
Ristori? \\
\end{tabular} & \\
\hline Majo, Giuseppe de & $1697-1771$ & Ristori? & $2475-$ \\
\hline Manzini [=Francesco Mancini] & $1672-1737$ & Zelenka & $2203-$ \\
\hline
\end{tabular}

56 Michael Driscoll advises that the psalms attributed to Fabri in Zelenka's collection are unique attributions found nowhere else. RISM listings attribute the setting to a variety of composers, mainly to one named 'Schmidt'.

57 This work is also listed in the Catalogo (1765) under the name 'Pietragrua', who almost certainly was the composer.

58 At the time of writing works of several composers supplied by Baldan are identified as being listed falsely under Galuppi's name. 
Italian Sacred Music listed in the Catalogue of Dresden's Catholic Court Church, 1765

\begin{tabular}{|c|c|c|c|}
\hline Name & Dates & Source & D-DI Mus. \\
\hline "Marenzio, Luca & $1553 / 4-1599$ & $\begin{array}{l}\text { Royal collection } \\
\text { Zelenka }\end{array}$ & $1160-$ \\
\hline "Monzino" [Carlo Monza? Franc ${ }^{\circ}$ Montini?] ${ }^{59}$ & & & $2768-$ \\
\hline Moro, Giulio & fl.1607 & Missing from D-DI & \\
\hline Negri, Luigi & b. 1718 & Ristori & $3846-$ \\
\hline Nelvi, Giuseppe Maria & $1698-1756$ & ? & $2499-$ \\
\hline Orlandini, Giuseppe Maria & $1676-1760$ & \begin{tabular}{|l|} 
Zelenka \\
Ristori
\end{tabular} & $2443-$ \\
\hline $\begin{array}{l}\text { Palestrina, Giovanni Pierluigi da [listed under } \\
\text { the names Palestina; Palestrino; Prenestini] }\end{array}$ & $1525-1594$ & $\begin{array}{l}\text { Zelenka } \\
\text { Ristori } \\
\text { Heinichen? }\end{array}$ & $\begin{array}{l}997- \\
2-\end{array}$ \\
\hline Pallavicino, Carlo & c. $1630-1688$ & $\begin{array}{l}\begin{array}{l}\text { Lutheran court chapel } \\
\text { (Dresden) }\end{array} \\
\end{array}$ & $1813-$ \\
\hline Passarino, Francesco Camillo & d. 1698 & Missing & \\
\hline Pergolesi, Giovanni Battista & $1710-1736$ & $\begin{array}{l}\text { Royal collection } \\
\text { Ristori } \\
\text { Baldan }\end{array}$ & $3005-$ \\
\hline Pescetti, Giovanni Battista & c. $1704-1766$ & Baldan & $2967-$ \\
\hline Piazzino [=Leandro Piazza: RISM] & & Unknown & $2875-$ \\
\hline Pietragrua [Pietro Grua], Carlo Luigi & c. $1665-1726$ & $\begin{array}{l}\text { Lutheran court chapel } \\
\text { (Dresden) } \\
\text { Ristori }\end{array}$ & 2221 \\
\hline Picinetti, Felice Maria & c. $1684-1754$ & Zelenka & $3161-$ \\
\hline Pisani, Giovanni & fl. 1720-38 & Zelenka & $2500-$ \\
\hline Pitoni, Giuseppe Ottavio & $1657-1743$ & \begin{tabular}{|l|} 
Zelenka \\
\end{tabular} & 2117 \\
\hline Pollarolo, Carlo Franc ${ }^{\circ}$ & $1676-1746$ & \begin{tabular}{|l|}
$\begin{array}{l}\text { Lutheran court chapel } \\
\text { (Dresden) }\end{array}$ \\
\end{tabular} & $2107-$ \\
\hline Pollarolo, Antonio & c. $1653-1723$ & Ristori & $2380-$ \\
\hline Porta, Giovanni & c. $1675-1755$ & Zelenka & $2444-$ \\
\hline Predieri, Luca Antonio & $1688-1767$ & Royal collection & $2425-$ \\
\hline Puppi, Antonio & fl. mid-18 $8^{\text {th }}$ century & Baldan & $3157-$ \\
\hline Ristori, Giovanni Alberto & $1692-1753$ & Ristori & $2455-$ \\
\hline Sarri [Sarro], Domenico Natale & $1679-1744$ & $\begin{array}{l}\text { Royal Music } \\
\text { Collection } \\
\text { Zelenka }\end{array}$ & $2356-$ \\
\hline
\end{tabular}

59 Information on this composer has not been found. The following works held in D-Dl have the same provenance: Canta (Giovanni Cantů): Kyrie e Gloria (Mus. 4975-D-1,2); Chiesa, Melchiore: Caelo tonanti [Motetti] No. 2 (Mus. 3284-E-1); Chiesa (Melchiore?): Gloria from Gloria e Credo (Mus. 3284-E-1); Monzino (Monza, Carlo Ignazio?): Kyrie e Gloria (Mus. 2768-D-1); Piazzino: (Messe) No. 2 Kyrie, Gloria, Credo (Mus. 2875-D-1; Mus. 2875-D-2). 
Italian Sacred Music listed in the Catalogue of Dresden's Catholic Court Church, 1765

\begin{tabular}{|c|c|c|c|}
\hline Name & Dates & Source & D-DI Mus. \\
\hline Seppi, Paolo (= Sepp, Paul) & $\begin{array}{l}\text { fl. Dresden 1666- } \\
1689\end{array}$ & $\begin{array}{l}\text { Lutheran court chapel } \\
\text { (Dresden) }\end{array}$ & 1901 \\
\hline *Silvani, Giuseppe Antonio & $1672-1727 / 8$ & $\begin{array}{l}\text { Catholic court church } \\
\text { (Dresden)? }\end{array}$ & 2198- \\
\hline Steffani, Agostino & $1654-1728$ & \begin{tabular}{|l|} 
Ristori \\
Zelenka \\
\end{tabular} & $2110-$ \\
\hline Tarantino [=Nicola Fago] & $1677-1745$ & \begin{tabular}{|l|} 
Royal collection \\
Ristori
\end{tabular} & $2200-$ \\
\hline Urio, Francesco Antonio & c. $1631-c 1719$ & Zelenka & $2141-$ \\
\hline Valle, Pietro & Not known & Unknown & $2878-$ \\
\hline "Vannini, Elia & c.1660-c1699 & \begin{tabular}{|l|}
$\begin{array}{l}\text { Catholic court church } \\
\text { (Dresden)? }\end{array}$ \\
\end{tabular} & 2036- \\
\hline Vignati, Giuseppe & d.1768 & Zelenka & $2246-$ \\
\hline Vitali Giovanni Battista & $1632-1692$ & \begin{tabular}{|l|}
$\begin{array}{l}\text { Lutheran court chapel } \\
\text { (Dresden) }\end{array}$ \\
\end{tabular} & $1875-$ \\
\hline Vivaldi, Antonio & $1768-1741$ & Zelenka & 2389- \\
\hline
\end{tabular}


